\title{
Analisis pengaruh ekspor ke China terhadap tingkat pengangguran di dua Negara di Kawasan Selat Malaka (Indonesia dan Malaysia)
}

\author{
Zamzami; Candra Mustika* \\ Prodi Ekonomi Pembangunan Fakultas Ekonomi dan Bisnis Universitas Jambi \\ *E-mail korespondensi: bluemickeyid@yahoo.com
}

\begin{abstract}
This study aims to analyze the development of Indonesian and Malaysian exports to China and the level of unemployment in both countries during the period 1993 to 2014 and analyze the effect of exports to China on the unemployment rate in both countries, namely Indonesia and Malaysia the development of the value of Indonesian exports to China. The results of the study showed that during the period 1993-2014 there were fluctuations from year to year with an average development rate over the period of $15.30 \%$ while the average export value during the period was 8,047.22 Million US dollars, the unemployment rate in Indonesia during the period 1993 - 2014 fluctuated or an increased and decrease with an average growth rate of $7.97 \%$. The regression results of the panel data model show that the value of exports to China does not significantly influence the number of unemployed people in Indonesia and Malaysia.
\end{abstract}

Keywords: Export and Unemployment

\begin{abstract}
Abstrak
Penelitian ini bertujuan untuk menganalisis perkembangan ekspor Indonesia dan Malaysia ke China dan tingkat pengangguran di kedua Negara tersebut selama periode tahun 1993 sampai tahun 2014 dan menganalisis pengaruh ekspor ke china tersebut terhadap tingkat pengangguran di kedua Negara tersebut yaitu Indonesia dan Malaysia perkembangan nilai ekspor Indonesia ke china Hasil penelitian menunjukkan selama periode tahun 1993-2014 mengalami fluktuasi dari tahun ke tahun dengan tingkat perkembangan rata-rata selama periode tersebut adalah $15.30 \%$ sedangkan rata-rata nilai ekspor selama periode tersebut adalah 8.047,22 Juta US dollar, angka pengangguran di Indonesia selama periode tahun 1993 - 2014 berfluktuasi atau mengalami peningkatan dan penurunan dengan rata-rata pertumbuhan adalah $7.97 \%$. Hasil regresi model data panel menunjukkan bahwa nilai ekspor ke china tidak berpengaruh signifikan terhadap jumlah pengangguran di Indonesia dan Malaysia.
\end{abstract}

Kata Kunci: Ekspor dan Pengangguran

\section{PENDAHULUAN}

Negara-negara di kawasan asia tenggara, apalagi saat ini pemberlakukan era perdagangan bebas Masyarakat Ekonomi Asean (MEA) merupakan peluang sekaligus tantangan bagi kinerja ekspor indonesia karena sejak beberapa tahun yang lalu pada tahun 1990 an Negara-negara di asia tenggara yang berada di sekitar selat Malaka seperti Malaysia,singapura dan Thailand merupakan daftar Negara tujuan ekspor, berdasarkan data Asia Development Bank (ADB) pada tahun 1990 nilai ekspor Indonesia ke Malaysia sebesar 253 Juta US Dollar dan pada tahun 2014 mencapai 9.759 Juta US Dollar,sementara nilai ekspor Indonesia ke Thailand pada tahun 1990 sebesar 189 Juta US Dollar dan pada tahun 2014 mencapai 5.830 Juta US Dollar dan Untuk ke 
singapura nilai ekspor pada tahun 1990 sebesar 1.902 Juta US Dollar dan pada tahun 2014 mencapai 16.052 Juta US Dollar.

Indonesia dan Malaysia merupakan dua Negara yang berada di kawasan asia tenggara tepatnya kawasan selat malaka, Indonesia dan Malaysia merupakan Negara yang termasuk menjalin kerjasama dengan Negara lain seperti china,malahan Indonesia dan Negara di kawasan asia tenggara termasuk Malaysia sudah membuka jalur perdagangan bebas dengan china melalui ACFTA (Asian China Free Trade Agreement) menurut catatan Bank Pembangunan Asia ekspor Indonesia ke China pada tahun 2014 senilai 17,606 Juta US Dollar sementara Nilai ekspor Malaysia ke China pada tahun 2014 senilai 28.204 Juta US Dollar, diharapkan dengan kerjasama Perdagangan dengan China mellaui ekspor dapat mengurangi tingkat pengangguran di masing-masing Negara karena salah satu dampak positif ekspor adalah makin meningkatnya permintaan tenaga kerja untuk memproduksi barang dan jasa yang akan di ekspor. Atas dasar latar belakang tersebut di atas lah yang melatar belakangi untuk melakukan penelitian dengan judul "Analisis Pengaruh Ekspor Ke China Terhadap Tingkat pengangguran di Dua Negara di kawasan selat Malaka (Indonesia dan Malaysia)

Setelah melihat uraian pada bagian latar belakang kita dapat mengidentifikasi masalah yang akan diteliti pada penelitian ini adalah bagaimana perkembangan ekspor Indonesia dan Malaysia ke China dan jumlah pengangguran di Indonesia dan Malaysia dari tahun 1993 sampai tahun 2014 dan bagaimana pengaruh ekspor ke China terhadap tingkat pengangguran di Negara Indonesia dan Malaysia selama periode tahun 1993 sampai 2014.

\section{METODE}

\section{Metode analisis}

Analisis Deskriptif

Merupakan analisis yang dilakukan secara deskriptif untuk memberikan gambaran mengenai perkembangan Variabel-variabel Penelitian, digunakan rumus yakni :

$$
\text { Igt }=\frac{\text { It }- \text { It }-1}{\text { It }-1} \times 100 \%
$$

Dimana:

Igt $=$ Perkembangan Variabel-variabel Penelitian (Nilai ekspor Indonesia dan Malaysia ke China dan Jumlah pengangguran di indonesia dan Malysia)

It $=$ Variabel Penelitian tahun $\mathrm{t}$

It-1 = Variabel Penelitian tahun $\mathrm{t}-1$

\section{Analisis kuantitatif}

Metode analisis data yang digunakan dalam penelitian ini adalah analisis regresi sederhana dengan metode data panel karena analisis tersebut dapat digunakan sebagai model prediksi terhadap suatu variabel dependen dari satu variabel independen yang menggunakan data time series dan cross section dengan model sebagai berikut yaitu :

$\mathrm{Uit}=\beta_{0}+\beta_{1} \mathrm{XC}_{\mathrm{it}}+\varepsilon$

Dimana :

$\mathrm{U} \quad$ : Pengangguran

XC : Nilai Ekspor ke China

i : Cross section (Indonesia dan Malaysia)

t : Tahun 1990 sampai 2014

$\beta_{0} \quad$ : Konstanta 
$\beta_{1} \quad: \quad$ Koefisien Regresi Variabel Independen (Nilai Ekspor)

$\varepsilon \quad: \quad$ Error term

\section{Rancangan uji hipotesis}

Model regresi linier berganda dapat disebut sebagai model yang baik jika model tersebut terbebas dari asumsi-asumsi klasik statistik, baik itu multikolinieritas, autokorelasi, dan heteroskesdastisitas.

Proses pengujian asumsi klasik statistik dilakukan bersama-sama dengan proses uji regresi sehingga langkah-langkah yang dilakukan dalam pengujian asumsi klasik statistik menggunakan media kotak kerja yang sama dengan uji regresi SPSS dan Eviews.

\section{Uji statistik t}

Digunakan untuk melihat signifikansi pengaruh variabel independen secara individu terhadap variabel dependen. Dalam penelitian ini menggunakan uji satu sisi, dengan hipotesis kedua seperti telah disebutkan diatas.

Nilai $\mathrm{t}$ hitung diperoleh dalam Gujarati 2003 dengan rumus :

$\mathrm{t}_{\text {hitung }}=\frac{\beta_{\mathrm{i}}}{\mathrm{S} \beta_{\mathrm{i}}}$

Dimana :

$\beta_{\mathrm{i}} \quad$ : Koefisien regresi variabel independen ke-i

$\mathrm{S} \beta_{\mathrm{i}} \quad$ : Standard error dari variabel independen ke-i

Dari perhitungan tersebut maka selanjutnya membandingkan anatara nilai t hitung dengan nilai t tabel pada tingkat keyakinan 95\% $(\alpha=0,05)$, dengan kriteria keputusan :

- Jika $\mathrm{t}_{\text {hitung }} \leq \mathrm{t}$ tabel $: \mathrm{H}_{0}$ diterima dan $\mathrm{H}_{\mathrm{a}}$ ditolak

- Jika $\mathrm{t}_{\text {hitung }}>\mathrm{t}$ tabel $: \mathrm{H}_{0}$ ditolak dan $\mathrm{H}_{\mathrm{a}}$ diterima

\section{HASIL DAN PEMBAHASAN}

\section{Perkembangan nilai ekspor Indonesia ke China}

Dari data pada gambar 1 dibawah dapat kita lihat bahwa perkembangan nilai ekspor Indonesia ke china selama periode tahun 1993 sampai 2014 mengalami fluktuasi dari tahun ke tahun dengan tingkat perkembangan rata-rata selama periode tersebut adalah $15.30 \%$ sedangkan rata-rata nilai ekspor selama periode tersebut adalah 8.047,22 Juta US dollar. Untuk melihat perkembangan nilai ekspor indonesia ke china dapat kita lihat pada Gambar 1 berikut ini :

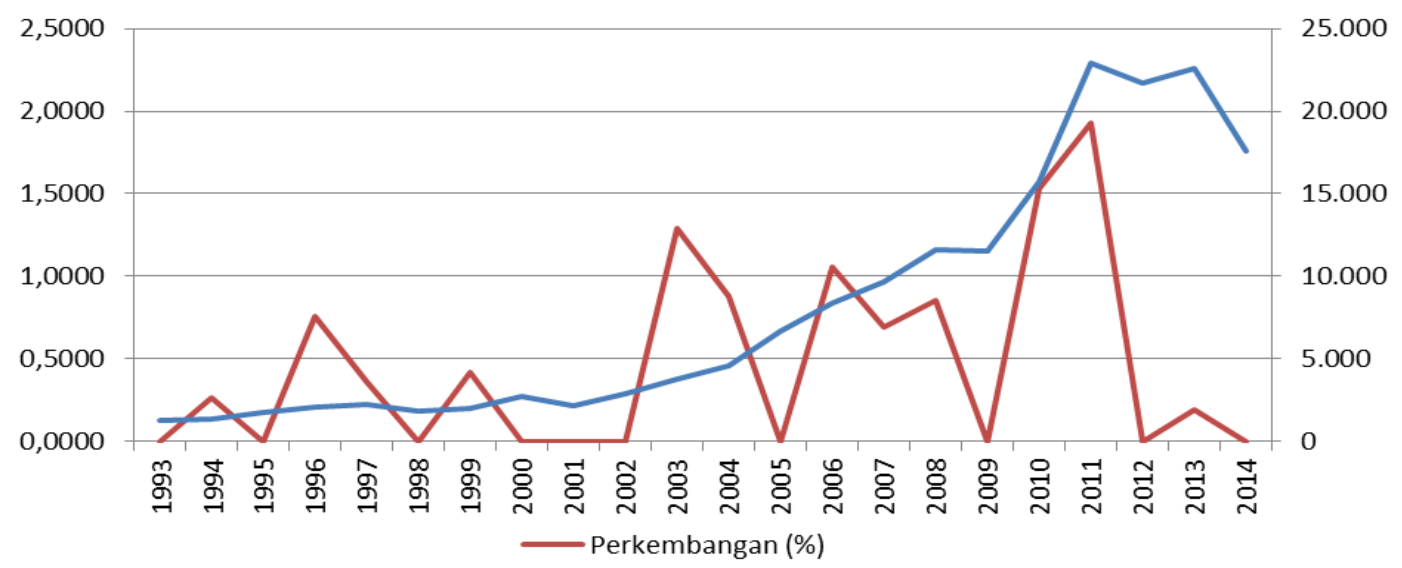

Sumber : ADB (Asian Development Bank)

Gambar 1 Perkembangan ekspor Indonesia ke China 1993-2014 


\section{Perkembangan pengangguran di Indonesia periode 1993-2014}

Selain investasi dan kemiskinan yang telah dijelaskan sebelumnya,salah satu indikator makro ekonomi yang mencerminkan keadaan baik atau buruknya ekonomi suatu Negara adalah jumlah tenaga kerja yang tidak bekerja atau angka pengangguran. Berikut ini disajikan tabel data perkembangan angka pengangguran di Indonesia selama periode 1993 sampai 2014 :

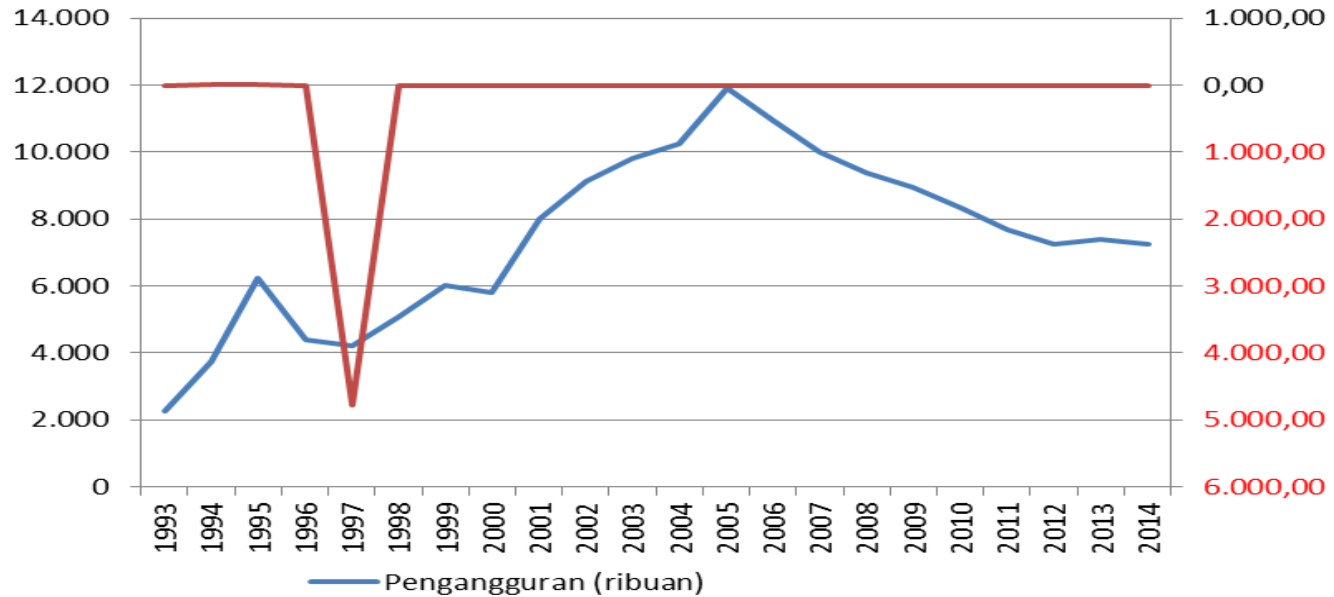

Sumber : ADB (Asian Development Bank)

Gambar 2 Perkembangan angka pengangguran di Indonesia periode 1993 _2014

Dari Gambar.2 terlihat bahwa angka pengangguran di Indonesia selama periode tahun 1993 sampai tahun 2014 berfluktuasi atau mengalami peningkatan dan penurunan dengan rata-rata pertumbuhan adalah 7.97

\section{Perkembangan nilai ekspor Malaysia ke china}

Untuk mengetahui perkembangan nilai ekspor Malaysia ke Negara Malaysia dapat dilihat pada tabel berikut ini :

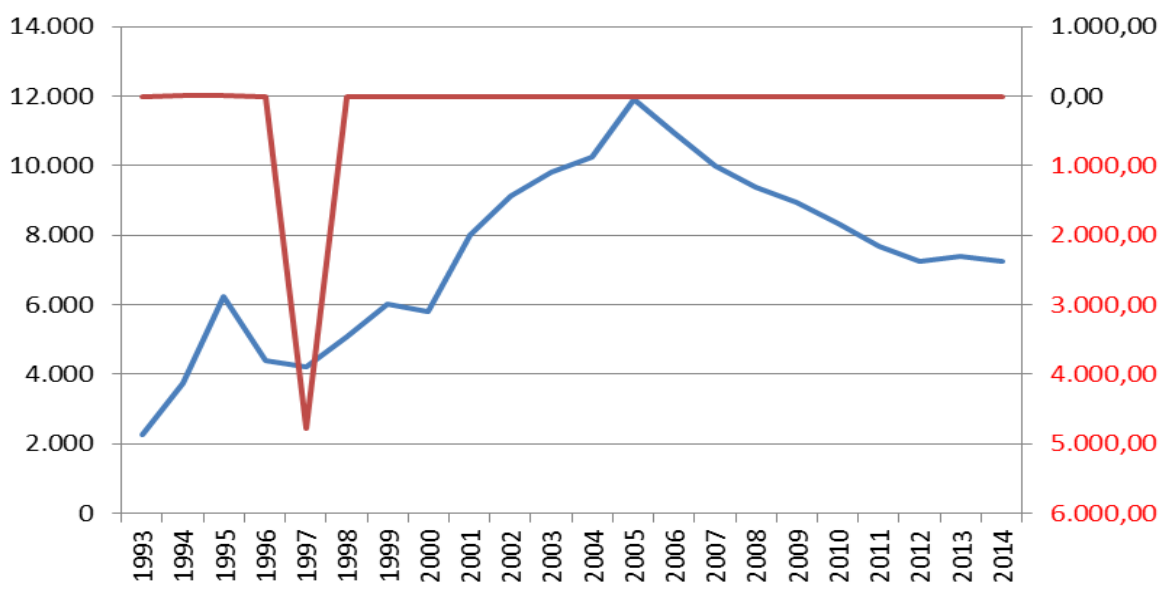

Sumber : ADB (Asian Development Bank)

Gambar 3 Perkembangan nilai ekspor Malaysia ke China 
Dari Gambar.3 terlihat bahwa perkembangan nilai ekspor Malaysia ke Negara china mengalami fluktuasi atau naik turun selama periode tahun 1993 sampai 2014 dengan nilai rata-ratanya sebesar 11.711,82 Juta US dollar dan dengan rata-rata tingkat pertumbuhannya $17,37 \%$,

\section{Perkembangan pengangguran di Malaysia periode 1993-2014}

Untuk mengetahui data jumlah pengangguran di Malaysia dapat dilihat pada tabel berikut ini :

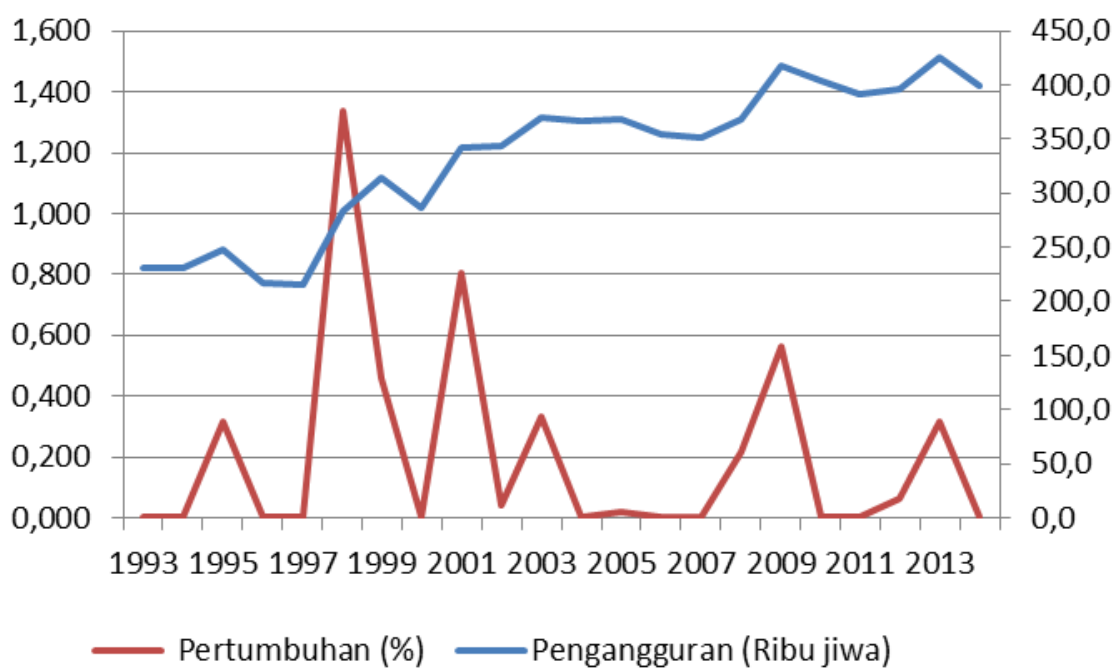

Sumber : ADB (Asian Development Bank)

Gambar 4 Perkembangan pengangguran di Malaysia

Dari Gambar 4 terlihat bahwa selama periode penelitian jumlah pengangguran di Malaysia mengalami fluktuasi atau naik turun dengan nilai rata-ratanya mencapai 333 ribu jiwa pertahun dengan rata-rata tingkat pertumbuhan sebesar 3,07\% pertahun, dari data diatas juga di peroleh selama periode penelitian tingkat pertumbuhan pengangguran tertinggi terjadi pada tahun 1998 yakni sebesar 32,09\% dan pertumbuhan terendah terjadi pada tahun 1996 yakni sebesar $12,5 \%$.

\section{Pengaruh ekspor ke china terhadap pengangguran di Indonesia dan Malaysia Hasil regresi model data panel}

Sebelum menentukan model panel terbaik terlebih dahulu melakukan Uji Hausman yang hasilnya dapat dilihat pada tabel berikut ini :

Tabel 1 Hasil Uji Hausman

Correlated Random Effects - Hausman Test

Pool: POOL

Test cross-section random effects

Test Summary

Chi-Sq. Statistic Chi-Sq. d.f. Prob.

\begin{tabular}{llll}
\hline Cross-section random & 176.114950 & 1 & 0.0000 \\
\hline
\end{tabular}

** WARNING: estimated cross-section random effects variance is zero.

Sumber : Data diolah,2017

Dari hasil uji hausman di peroleh hasil nilai Chi square yang signifikan sehingga Ho ditolak Ha di terima jika Ho adalah random efefect maka Ha adalah fixed effect 
dengan demikian model yang terbaik adalah fixed effect yakni dapat dilihat pada tabel berikut ini :

Tabel 2 Hasil regresi fixed effect

\begin{tabular}{crlll}
\hline \multicolumn{1}{c}{ Variable } & Coefficient & Std. Error & t-Statistic & Prob. \\
\hline C & 3531.257 & 395.7149 & 8.923739 & 0.0000 \\
X? & 0.036866 & 0.029455 & 1.251608 & 0.2178 \\
Fixed Effects (Cross) & & & \\
IND--C & 3630.027 & & \\
_MAL--C & -3630.027 & & \\
\hline \multicolumn{5}{c}{ Effects Specification } \\
Cross-section fixed (dummy variables) & & \\
R-squared & 0.812836 & Mean dependent var & 3895.477 \\
Adjusted R-squared & 0.803706 & S.D. dependent var & 4014.780 \\
S.E. of regression & 1778.753 & Akaike info criterion & 17.87096 \\
Sum squared resid & $1.30 \mathrm{E}+08$ & Schwarz criterion & 17.99261 \\
Log likelihood & -390.1611 & Hannan-Quinn criter. & 17.91607 \\
F-statistic & 89.02942 & Durbin-Watson stat & 0.215323 \\
Prob(F-statistic) & 0.000000 & & \\
\hline Sumber : Data diol & \multicolumn{5}{c}{} \\
\hline
\end{tabular}

Sumber : Data diolah,2017

Sehingga di peroleh persamaan untuk masing-masing cross section adalah:

U_IND $=3630.02700269+3531.25703152+0.0368661777765 *$ X_IND

U_MAL $=-3630.02700269+3531.25703152+0.0368661777765 * \bar{X} \_\mathrm{MAL}$

\section{Hasil uji t statistik}

Dari hasil regresi di peroleh nilai t hitung sebesar 1,25 dan nilai probabilitas nya 0,21 melebihi batas signifikansi level 10\% sehingga dengan demikian hipotesis di tolak artinya nilai ekspor ke china tidak berpengaruh signifikan terhadap pengangguran di Negara Indonesia dan Malaysia.

\section{Implikasi hasil penelitian}

Dari hasil penelitian menunjukkan bahwa ternyata nilai ekspor Indonesia dan Malaysia ke china tidak berpengaruh signifikan terhadap jumlah pengangguran hal ini dapat dijelaskan karena adanya transmisi ekonomi yang cukup jauh antara ekspor dan pengangguran, untuk mempengaruhi jumlah pengangguran perlu variabel lainnya seperti tingkat produksi atau output di dalam negeri yang memenuhi kapasitas sehingga peningkatan output baru dapat meningkatkan permintaan akan tenaga kerja tetapi komoditas barang ekspor belum tentu membutuhkan tenaga kerja yang banyak sehingga tidak akan mempengaruhi tingkat pengangguran yang ada.

Komoditas ekspor Indonesia yang di dominasi oleh barang-barang non migas dan sebagian besar adalah berasal dari sektor pertanian dengan tingkat produktivitas yang masih rendah dan tenaga kerja yang bekerja di sektor ini semakin lama semakin turun sehingga dapat di simpulkan ternyata variabel ekspor memerlukan beberapa transmisi dari variabel lain seperti output niali produksi dan jumlah tenaga kerja sehingga perlu kajian yang lebih baik lagi untuk menggunakan variabel ekspor untuk mempengaruhi pengangguran. 


\section{KESIMPULAN DAN SARAN}

\section{Kesimpulan}

Perkembangan nilai ekspor Indonesia ke china selama periode tahun 1993 sampai 2014 mengalami fluktuasi dari tahun ke tahun dengan tingkat perkembangan rata-rata selama periode tersebut adalah $15.30 \%$ sedangkan rata-rata nilai ekspor selama periode tersebut adalah 8.047,22 Juta US dollar,dalam kurun periode tersebut perkembangan ekspor tertinggi terjadi pada tahun 2011 yakni sebesar 46,18 dan tingkat perkembangan terendah atau mengalami penurunan tertinggi pada periode tersebut terjadi pada tahun 2014 yakni sebesar-22,10\% . angka pengangguran di Indonesia selama periode tahun 1993 sampai tahun 2014 berfluktuasi atau mengalami peningkatan dan penurunan dengan rata-rata pertumbuhan adalah $7.97 \%$, pertumbuhan tertinggi terjadi pada tahun 1995 yakni 67,22\% dan terendah pada tahun 1996 yakni -29,48\%. nilai ekspor Malaysia ke Negara china mengalami fluktuasi atau naik turun selama periode tahun 1993 sampai 2014 dengan nilai rata-ratanya sebesar 11.711,82 Juta US dollar dan dengan rata-rata tingkat pertumbuhannya $17,37 \%$, nilai pertumbuhan tertinggi terjadi pada awal periode penelitian yakni pada tahun 1994 sebesar 60,54\% dan pertumbuhan terendah pada tahun 1995 yakni $-2,27 \%$. penelitian jumlah pengangguran di Malaysia mengalami fluktuasi atau naik turun dengan nilai rata-ratanya mencapai 333 ribu jiwa pertahun dengan ratarata tingkat pertumbuhan sebesar $3,07 \%$ pertahun, dari data diatas juga di peroleh selama periode penelitian tingkat pertumbuhan pengangguran tertinggi terjadi pada tahun 1998 yakni sebesar 32,09\% dan pertumbuhan terendah terjadi pada tahun 1996 yakni sebesar $12,5 \%$. Sedangkan hasil regresi model data panel menunjukkan bahwa nilai ekspor ke china tidak berpengaruh signifikan terhadap jumlah pengangguran di Indonesia dan Malaysia.

\section{Saran}

Pengangguran masih merupakan salah satu masalah dalam ekonomi makro yang di hadapi oleh Negara-negara maju maupun sedang berkembang termasuk Indonesia dan Malaysia sehingga perlu upaya yang serius bagi pemerintah Indonesia dan Malaysia untuk mengatasi masalah pengangguran serta perlu adanya evaluasi dengan adanya kerjasama perdagangan bebas dengan china dalam meningkatkan nilai ekspor ke Negara china. Bagi peneliti lanjutan perlu mengevaluasi variabel lain selain ekspor yang dapat digunakan dalam menganalis pengaruhnya terhadap pengangguran atau dengan pendekatan model yang lebih baik sehingga terdapat transmisi hubungan secara langsung atau tidak langsung atau menggunakan persamaan simultan.

\section{DAFTAR PUSTAKA}

ADB.(2014). Economic Indicators from : www.adb.org

Agus,Salim.(2005). Analisis Keterkaitan Antara Pengeluaran Pemerintah Pertumbuhan Ekonomi Ketimpangan Distribusi Pendapatan dan Kemiskinan di Indonesia 19762004, Disertasi Program Pascasarjana UNPAD (tidak dipublikasikan).

Arman Delis.;Candra Mustika.;Etik Umiyati.(2015).Pengaruh FDI terhadap Kemiskinan dan Pengangguran di Indonesia. Jurnal Paradigma Ekonomika, 10(1); 231-245.

Badan pusat statistik . Indikator sosial Ekonomi Indonesia berbagai Edisi.BPS Pusat. Dornbusch.R.(2001).Macro Economic, The Mc Graw Hill Companies Inc: New york 
Dumairy.(1996). Perekonomian Indonesia : PT. Airlangga. JakartaGaspersz, Vincent. 1997: Jakarta.

Greene,H.William.(2000). Econometric Analysis, $4^{\text {th }}$ Edition, Prentice-Hall: New Jersey.

Gujarati,Damodar N.(2003). Basic Econometrics.. Fourth edition, International Edition. MC Grow Hill.

Lindert, Peter H.(1994). Ekonomi Internasional (Edisi 9), Bumi Aksara: Jakarta.

M,Wardiansyah.;Yulmardi.;Zainul,Bahri.(2017).Analisis Faktor-Faktor Yang Mempengaruhi Tingkat Pengangguran (Studi Kasus Provinsi-Provinsi SeSumatera). Jurnal Paradigma Ekonomika, 5(1); 13-18.

Mankiw, N. Gregory.(2003). Teori Makro Ekonomi. Alih Bahasa Iman Nurmawan dan Editor Wisnu C Kristiadi.

Marius,Jelamu,A.(2004).Memecahkan masalah Pengangguran di Indonesia,Makalah, IPB

Meidiana.(2010). Analisis Pengaruh Ekspor terhadap Pertumbuhan Ekonomi Indonesia Periode 2003.1- 2010.10. Skripsi Fakultas Ekonomi Universitas Lampung.

Mudrajad,Kuncoro.(2003). Metode Riset untuk Bisnis dan Ekonomi : Bagaimana Meneliti dan Menulis Tesis?, Jakarta : Erlangga.

Pitartono.(2012). Analisis Tingkat Pengangguran di Jawa Tengah Tahun 1997-2013. Skripsi S1, Program Sarjana Fakultas Ekonomika dan Bisnis Universitas Diponegoro

T.Froyen.(2005).Macro Economics, Theories and Policies, Eight Edition: Pearson Prentice Hall.

Todaro, Michael P.;Stephen C.Smith.(2003). Economic Development, Eight Edition:The Addison.Wesley.

Van den Berg.;Hendrik.(2001). Economic Growth and Development,International Edition, The Mc Graw Hill Companies.Inc. 